\title{
Review
}

\section{The work of politics: Making a democratic welfare state}

\author{
Steven Klein \\ Cambridge University Press, Cambridge, 2020, 204pp., \\ ISBN: 9781108778398
}

Contemporary Political Theory (2022) 21, S15-S18. https://doi.org/10.1057/s41296020-00462-w; published online 14 January 2021

The welfare state has shrunk considerably — both in terms of its reach and the safety net it offers-since its postwar heyday. Economically the increasing pressure of globalization has driven a race to the bottom in both taxes and benefits, while politically the neoliberal ideology of market fundamentalism has increasingly privatized public services. As a result, citizens are progressively forced to take on consumer debt to finance the social protections they used to receive directly from the state.

In light of these developments, progressive thinkers today tend to recall the golden age of the welfare state with a certain nostalgia. This makes it easy to forget that during the postwar era political theorists were actually quite wary of social welfare. In particular, many leading thinkers feared that the welfare state would replace potentially transformative political movements with the technical management of economic interests based on bureaucratic instrumental rationality.

Looking back on these claims from the perspective of the present, in The Work of Politics Steven Klein disputes this overly narrow, pessimistic understanding of the welfare state by providing an account of 'welfare institutions that shows how they can function, not as bureaucratic, passive-client-creating entitlements, but as mechanisms for collective democratic empowerment and participation' (p. 2). This argument is not purely theoretical; Klein explicitly notes that 'it is oriented to th[e] new political currents' (xi) of the present by highlighting how welfare institutions present 'both opportunities and risks for democratic social movements' (p. 176).

Klein's book is organized around a critique of Max Weber's vision of bureaucratic administration-including welfare institutions-as an instrument of technical domination that can only be opened up to popular control by charismatic leaders in moments of extraordinary politics. He pushes back against this prevailing understanding of the welfare state as a hierarchical machine for the calculation of economic interests by showing how these institutions also have the potential to bring individuals together in social movements by opening 'hidden forms of

(C) 2021 The Author(s), under exclusive licence to Springer Nature Limited part of Springer Nature. 14708914 Contemporary Political Theory Vol. 21, S1, S15-S18

www.palgrave.com/journals 
domination to critical challenge and transformative political action' (p. 4). In making this point, Klein draws on a number of historical examples, focusing on the political mobilizations enabled by both Otto von Bismarck's creation of the first welfare institutions in Prussia and the development of the postwar Swedish welfare state.

While these case studies play an important part in The Work of Politics, its argument is primarily theoretical. Despite the fact that they both expressed skepticism towards the bureaucratization of political life, Klein allies himself with Hannah Arendt and Jürgen Habermas. While Arendt is often interpreted as defending an account of the political as autonomous from economics, The Work of Politics deploys her work to show how welfare institutions, as structures created by political action, can act as 'worldly mediators' that provide 'a way of analyzing economic activities as always exceeding the terms of instrumentality and technical control' (p. 112). Similarly, Klein adapts Habermas's distinction between three forms of validity - the subjective, intersubjective, and objective-to reveal the different 'faces' of domination.

This is a wonderful book. It is a must read for anyone interested in the history of the welfare state and its potential to spark social movements in the future. Additionally, Klein's application of Habermas to neo-republican, neo-Kantian, and post-structuralist accounts of domination is brilliant. He does an excellent job of demonstrating how toggling between the third person perspective of objective domination, the second person standpoint of intersubjective domination, and the first person perspective of internal domination via subjectification can provide a fuller account of domination than any one of these accounts.

The way Klein draws on the 'unexpected support' (Verovšek 2014) of both Arendt and Habermas in developing his account of how 'the formation of welfare institutions renders explicit submerged relations and structures of domination, exposing them to political challenge and critique', (p. 28) is also compelling and provides an interesting new perspective on both of these theorists. By pushing back against the hostility political theorists have traditionally displayed towards the welfare state, The Work of Politics is undoubtedly an important contribution to contemporary political philosophy at a time when debates about welfare institutions are back on the political agenda.

It is unclear, however, if Klein succeeds in 'discern[ing] a mode of relating to bureaucratic institutions such as welfare institutions that helps reveal the democratic possibilities they offer' (p. 61). In setting this as his goal, Klein is part of a broader movement among young political theorists to recapture the emancipatory potential of administration. For example, Blake Emerson's (2019) recent monograph focuses on the transformative potential of popular participation in the administrative state, while Bernardo Zacka (2017) tackles this issue from the opposite direction by offering a bottom-up view of how frontline social workers act as moral agents by exercising bureaucratic discretion.

S16 (c) 2021 The Author(s), under exclusive licence to Springer Nature Limited part of Springer Nature. 14708914 Contemporary Political Theory Vol. 21, S1, S15-S18 
By contrast, while Klein's goal is to show the democratic potential of bureaucratic administration, he actually tends to focus on the policies of the welfare state as discursive catalysts for new forms of political participation, not on these institutions as 'important sites of political mobilization' per se (p. 171). For example, the socialist responses to Bismarck's social insurance laws and the various ways Swedish feminists used family politics to undermine patriarchy that Klein describes actually reflect changes in political debate and the politicization of social issues in civil society and parliament, not within the bureaucratic institutions of the welfare state as such.

This distinction is important, because it shifts the focus from the apolitical, deadening effects of bureaucratic management-the actual concern shared by Weber, Arendt, and Habermas - to the political debates that these governmental interventions in social policy enable by recognizing previously invisible subaltern groups or giving underrepresented individuals the ability and vocabulary to advance their claims. The key question for all of these thinkers is thus not the 'autonomy of the political' (p. 8), as Klein describes it, but its primacy over the economic and administrative systems that can potentially hinder political mobilization. While The Work of Politics succeeds in contesting 'the conceptual vocabulary brought to bear by democratic theory [which] reinforces an image of bureaucratic institutions as being inherently anti-democratic' (p. 11), the mechanism for this mobilization of welfare is the discourse that these policies bring about, not welfare institutions as such.

I do not have the space to provide a thorough analysis of Klein's innovative and suggestive reading of Habermas. Overall, The Work of Politics displays a clear preference for Habermas's early work, particularly Knowledge and Human Interests (1968), which was based on Marxist categories of class, to his later, more neo-Kantian analyses of language. While there are reasons for this choice, I think than Klein's analysis relies on far too sharp a distinction between these two stages in Habermas's thought. While this is not necessarily a problem in the abstract, it is somewhat strange, as Klein's critique of Habermas's move from structural to abstract forms of domination seems to undercut the organization of The Work of Politics around the insight that different forms of domination continue to exist and that we need Habermas's complete framework of the three spheres of validity, which is drawn from his later work, to obtain a complete understanding of this phenomenon.

Klein's focus on Habermas's early work also leads him to overlook some important resources from Habermas's more recent thinking that would have been useful for his argument. For example, I was surprised by only one mention of the 'colonization of the lifeworld' (p. 48) in The Work of Politics - and even that only in passing-even though this concept highlights the dangers of allowing the economic logic of social welfare to 'colonize' public debate by making political choices about the structure of the shared 'lifeworld' of a political community seem

(C) 2021 The Author(s), under exclusive licence to Springer Nature Limited part of Springer Nature. 1470- S17

8914 Contemporary Political Theory Vol. 21, S1, S15-S18 
like objective calculations of need, a fear that Klein shares. The result-and this is Habermas's (1992) main worry-is that this process encourages individual citizens to think of their basic rights as calculable economic interests that can be assigned a monetary value and traded against each other. This is a constant danger, and one that Klein wants to mitigate in making his argument, as he is aware of the many ways that 'institutions threaten to absorb the transformative energies of democratic movements into the status quo' (p. 10).

In highlighting examples of world-building through the welfare state, Klein is right to push back on the predominant, overly totalizing view of the effects of welfare state entitlements within political theory. However, whereas Habermas (as well as Weber and Arendt) may be too pessimistic about the democratic potential of welfare institutions, Klein is probably too optimistic. While he is right to point to welfare institutions as creating 'opportunities for democratic participation and engagement' (p. 3), such positive outcomes are hardly inevitable, and may even be unlikely.

The real question is not whether welfare policies spark political engagement or apathy, but when and under what conditions they do the latter rather than the former. By highlighting their potential, Klein opens an important new field for the political theory of the welfare state. But there is much more work to be done in exploring the crucial question he opens up regarding the ways in which the welfare state 'present[s] both opportunities and risks for democratic social movements' (p. 176).

\section{References}

Emerson, B. (2019). The public's law: Origins and architecture of progressive democracy. Oxford: Oxford University Press.

Habermas, J. (1992). Between facts and norms: Contributions to a discourse theory of law and democracy. Cambridge: MIT Press.

Verovšek, P. J. (2014). Unexpected support for european integration: Memory, rupture and totalitarianism in arendt's political theory. The Review of Politics, 76(3), 389-413.

Zacka, B. (2017). When the state meets the street: Public service and moral agency. Cambridge: Harvard University Press.

Publisher's Note Springer Nature remains neutral with regard to jurisdictional claims in published maps and institutional affiliations.

Peter J. Verovšek University of Sheffield, Sheffield S10 2TU, UK p.j.verovsek@sheffield.ac.uk

S18 (c) 2021 The Author(s), under exclusive licence to Springer Nature Limited part of Springer Nature. 14708914 Contemporary Political Theory Vol. 21, S1, S15-S18 